\title{
Differential effects of the charge variants of human follicle-stimulating hormone
}

\author{
C M Timossi ${ }^{1,2}$, J Barrios-de-Tomasi ${ }^{2}$, R González-Suárez ${ }^{3}$, \\ M Celeste Arranz ${ }^{3}$, V Padmanabhan ${ }^{4}$, P M Conn ${ }^{5}$ and \\ A Ulloa-Aguirre ${ }^{2,5}$

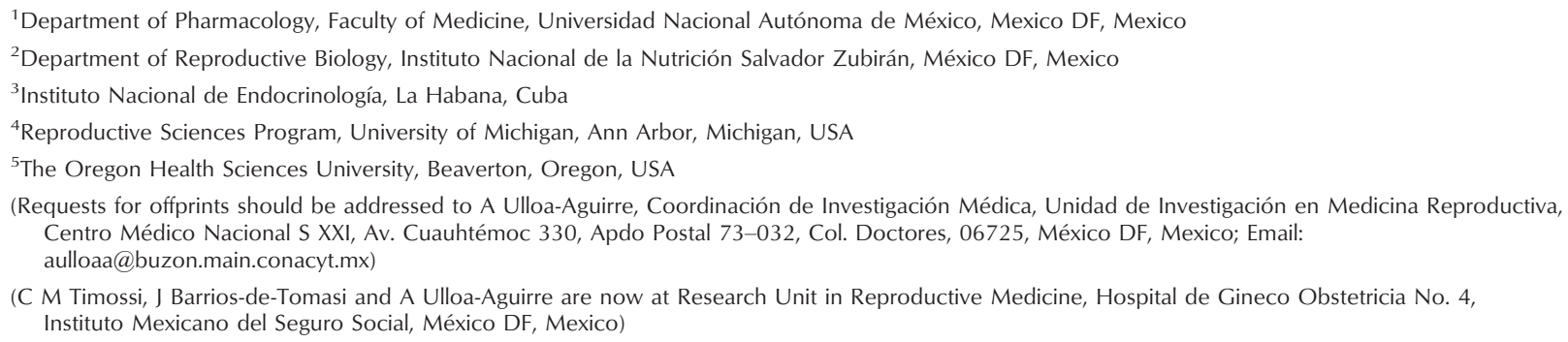

\section{Abstract}

FSH is synthesized and secreted by the anterior pituitary gland in multiple molecular forms; the release of these isoforms depends on the endocrine status of the donor at the time of sample collection. In the present study, we analysed the possibility that the FSH charge isoforms may exert differential effects at the target cell. Seven FSH isoform mixes were isolated from pooled anterior pituitary glycoprotein extracts by high resolution chromatofocusing, followed by affinity chromatography, which removed nearly $90 \%$ of the $\mathrm{LH}$ that co-eluted with the FSH isoforms during chromatofocusing. The isoforms (isoform I, $\mathrm{pH}>7 \cdot 10$; II, pH range 6.60-6.20; III, pH 5.47-5.10; IV, $\mathrm{pH}$ 5.03-4.60; V, pH 4.76-4.12; VI, pH 4.05-3.82 and VII, $\mathrm{pH}<3 \cdot 80$ ) were then tested for their capacity to stimulate cAMP release, androgen aromatization and tissue-type plasminogen activator (tPA) enzyme activity and cytochrome P450 aromatase, tPA and inhibin $\alpha$-subunit mRNA production by rat granulosa cells in culture. cAMP and oestradiol production were determined by RIA, tPA enzyme activity by SDS-PAGE and zymography and all mRNAs by northern blot hybridization
\end{abstract}

analysis and semiquantitative RT-PCR. All isoforms, with the exception of isoform I, stimulated synthesis and release of cAMP, oestrogen and tPA enzyme activity in a dosedependent manner; the potency of the less acidic isoforms (pH 6.60-4.60) was greater than that exhibited by the more acidic/sialylated analogs $(\mathrm{pH} 4.76$ to $<3.80$; potencies II $>$ III $>$ IV $>$ V $>$ VII $>$ VI). A similar trend was observed in terms of cytochrome $\mathrm{P} 450$ aromatase and tPA mRNA production. In contrast, when FSH-stimulated production of $\alpha$-inhibin mRNA was analysed, isoforms V-VII were significantly more potent (two- to threefold) than the less acidic/sialylated counterparts (II-IV). In contrast to isoforms II-VII (which behaved as FSH agonists), isoform I (elution $\mathrm{pH}>7 \cdot 10$ ) completely blocked P450 aromatase and tPA mRNA expression, without altering that of a constitutively expressed gene (glyceraldehyde-3-phosphate dehydrogenase). These results show for the first time that the naturally occurring human FSH isoforms may exhibit differential or even unique effects at the target cell level.

Journal of Endocrinology (2000) 165, 193-205

\section{Introduction}

The pituitary gonadotrophin follicle-stimulating hormone (FSH) regulates the development and maintenance of several basic reproductive processes, including gametogenesis, follicular maturation and ovulation (Chappel et al. 1983). This gonadotrophin is a member of a glycoprotein hormone family that includes luteinizing hormone ( $\mathrm{LH})$, thyroid-stimulating hormone (TSH) and choriogonadotrophin and consists of a common $\alpha$-subunit and a unique $\beta$-subunit (Pierce et al. 1971, Boothby et al. 1981, Pierce \& Parsons 1981). Each subunit has two asparagine-linked (N-linked) oligosaccharides, attached at positions 52 and 78 on the $\alpha$-subunit and at positions 7 and 24 on the $\beta$-subunit of human FSH (Baenzinger \& Green 1988). These play a significant role in determining the plasma 
half-life, specific interaction with the target-cell receptor and capability of the hormone to activate one or more intracellular signal transduction pathways (Morell et al. 1971, Sairam \& Bhargavi 1985, Sairam 1989, Flack et al. 1994b, Valove et al. 1994, Arey et al. 1997). In all glycoprotein hormones, the oligosaccharides are highly variable (Baenzinger \& Green 1988). Recent evidence indicates that, regardless of sex, this variability is strongly influenced by the endocrine milieu of the donor at the time of tissue or sample collection (Padmanabhan et al. 1988, Wide \& Bakos 1993, Zambrano et al. 1995, Anobile et al. 1998). Variations in the oligosaccharide structures on these glycoprotein hormones constitute the main biochemical basis for isoform formation and the large array of molecular forms found within the pituitary gland and in the circulation (Ulloa-Aguirre et al. 1995).

FSH isoforms may be separated on the basis of their charge, determined by the structure and distribution of sialylated $N$-linked oligosaccharide structures (Baenzinger \& Green 1988, Ulloa-Aguirre et al. 1995). Although in both the pituitary gland and serum the relative proportion of highly acidic/sialylated isoforms predominates over that of the less sialylated forms, the latter variants substantially increase during the periovulatory period (Padmanabhan et al. 1988, Wide \& Bakos 1993, Zambrano et al. 1995, Anobile et al. 1998). As a consequence of their structural differences, FSH isoforms differ in their capability to bind to target-cell receptors, survive in the circulation and evoke biological responses (Ulloa-Aguirre et al. 1988a, 1992, Yding Andersen et al. 1999, Zambrano et al. 1999). Highly acidic/sialylated isoforms have considerably longer plasma half-lives but more modest and/or slower capacities to elicit cellular responses in vitro and in vivo (Wide 1986, Ulloa-Aguirre et al. 1992, Timossi et al. 1998b, Vitt et al. 1998, Barrios de Tomasi et al. 1999, Yding Andersen et al. 1999). Although studies in a variety of species and in humans have clearly demonstrated heterogeneity of FSH (and other glycoprotein hormones), the functional significance of such a variety of isoforms for a single hormone remains unclear. In this regard, we have previously proposed (Ulloa-Aguirre et al. 1995) that at least three criteria must be met to assign physiological and clinical significance to FSH heterogeneity: isoforms identified in the anterior pituitary gland must be secreted into the circulation and reach the target cell, circulating FSH isoforms must be differentially regulated by the endocrine milieu, and changes in the distribution of circulating isohormones during different physiological conditions must be of sufficient magnitude to alter the net potency of the hormone or, alternatively, the biological actions rather than potencies must differ among the various isoforms. Although abundant evidence exists from several laboratories in support of the first two criteria (Padmanabhan et al. 1988, Wide \& Bakos 1993, Zambrano et al. 1995, Phillips et al. 1997, Anobile et al. 1998), evidence supporting the third is somewhat circumstantial (Zambrano et al. 1995, Timossi et al. 1998a). Limited studies comparing chemically derived ovine FSH isoform mixes have shown that deglycosylated FSH is less potent than the native FSH variant in stimulating cAMP and oestrogen production, but more potent in provoking $\alpha$-inhibin production (Beitinz \& Padmanabhan 1991, Ulloa-Aguirre et al. 1995). Similar studies using natural variants testing the potential differential functions have not been undertaken.

In the present study we explored the possibility that naturally occurring, pituitary-derived FSH isoforms may exert differential effects at the target cell level. To investigate this issue, we analysed the effects of seven anterior pituitary FSH charge isoform mixes on granulosa cell function, monitoring the FSH-induced generation of two different end products (oestradiol-17 $\beta$ ) and tissue-type plasminogen activator (tPA) with their corresponding mRNAs, in addition to expression of $\alpha$-inhibin mRNA, which is also under the control of this gonadotrophin.

\section{Material and Methods}

\section{Pituitary extracts}

Adult human pituitaries from victims of accidental death were collected at autopsies performed no later than $24 \mathrm{~h}$ postmortem. No selection was made for age and sex and the bodies were kept at $8{ }^{\circ} \mathrm{C}$ within $3-4 \mathrm{~h}$ after death. The anterior pituitary glands were stored frozen at $-70{ }^{\circ} \mathrm{C}$ until extracts were prepared. Total anterior pituitary glycoprotein extracts from two different batches of pooled pituitaries were obtained by the method of Jones et al. (1979). Extracts were mixed, separated in several aliquots and kept frozen at $-70{ }^{\circ} \mathrm{C}$ until required for chromatofocusing. The study was approved by the human and animal research ethics committees of the Institute at which the work was conducted.

\section{Preparative chromatofocusing of pituitary glycoprotein extracts and LH immunoextraction}

High-resolution chromatofocusing of FSH contained in the two pooled batches of pituitary glycoprotein extracts was performed as described previously (Zambrano et al. 1996, Timossi et al. 1998a). After RIA determination of $\mathrm{LH}$ and FSH contained in 5-15 $\mu \mathrm{l}$ aliquots of each fraction collected from three chromatofocusing separations, fractions containing the greatest concentrations of immunoactive FSH (within a $\mathrm{pH}$ gradient of $7 \cdot 10$ to $3 \cdot 8$ ) and those recovered at both ends of the $\mathrm{pH}$ window (elution $\mathrm{pH}$ values $>7 \cdot 10$ and $<3.8$ ) were pooled as shown in Fig. 1. The pools were transferred to dialysis membrane tubes (molecular mass cut-off 12 000-14000 Da), dialysed for $24 \mathrm{~h}$ at $4{ }^{\circ} \mathrm{C}$ against deionized water and then against $0 \cdot 01 \mathrm{M}$ ammonium carbonate, $\mathrm{pH}$ 7.5. The dialysed 


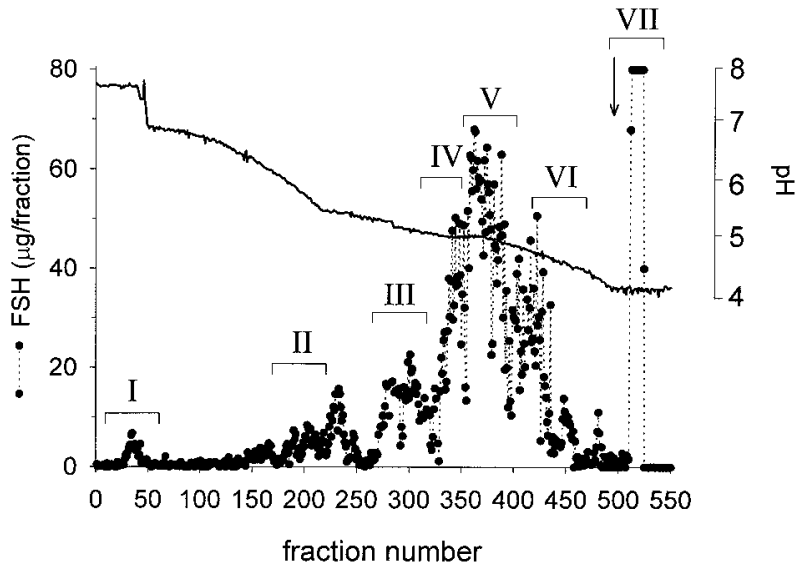

Figure 1 The pattern of $\mathrm{pH}$ distribution of pituitary $\mathrm{FSH}$ after chromatofocusing of an anterior pituitary glycoprotein extract. The fractions pooled to obtain the various FSH isoform concentrates (I-VII) are denoted by the brackets. The arrow indicates the addition of $1 \mathrm{M} \mathrm{NaCl}$ to the chromatofocusing column.

solution was dried by lyophilization. Powders containing each isoform pool (I-VII in Fig. 1) were then redissolved in $0 \cdot 1 \mathrm{M}$ ammonium bicarbonate $\mathrm{pH} 7 \cdot 4$ and transferred to $1 \times 10 \mathrm{~cm}$ columns of monoclonal antiLH-IgG (antiLH-BG7; Cuba-Mexico World Health Organization RIA Reagents Program, Mexico DF, Mexico) immobilized in Sepharose 4B (Pharmacia Fine Chemicals, Piscataway, NJ, USA) in order to remove the LH that co-eluted with the isoforms during the chromatofocusing separation. This procedure removed $>90 \%$ of the immunoreactive LH present in each original concentrate as determined by RIA. Each isoform concentrate was finally redissolved in McCoy's 5A modified medium (Gibco Brl, Gaithersburg, MD, USA) and stored frozen at $-70{ }^{\circ} \mathrm{C}$ until required for use. Both prolactin and growth hormone were undetectable in the final solutions of the different isoform pools used in the experiments when analysed at different dilutions by highly specific RIAs.

\section{Granulosa cell culture and in vitro bioassays of FSH}

Granulosa cells were collected by follicular puncture of ovaries from 21-day-old Wistar rats implanted for 4 days with diethylstilboestrol (Sigma Chemical Co., St Louis, MO, USA)-containing silastic capsules and cultured in $16 \mathrm{~mm} 24$ well plates at a density of $1.0-1.5 \times 10^{5}$ cells $/ \mathrm{ml}$ in McCoy's 5A medium supplemented with $2 \mathrm{mM}$ L-glutamine (Sigma), $100 \mathrm{U} / \mathrm{ml}$ penicillin and $100 \mu \mathrm{g} / \mathrm{ml}$ streptomycin (Gibco) in $5 \% \mathrm{CO}_{2}$ at $37^{\circ} \mathrm{C}$ and $80 \%$ humidity. After $24 \mathrm{~h}$ the cells were washed with unsupplemented medium and then incubated in the presence or absence of the various $\mathrm{FSH}$ isoforms or standards added to $500 \mu \mathrm{l}$ fresh McCoy's medium supplemented with L-glutamine, antibiotics, $0 \cdot 125 \mathrm{mM}$ methyl-isobutyl-xantine (MIX) (Sigma) and $10^{-6} \mathrm{M}$ androstenedione (Sigma). At the end of the culture period $(48 \mathrm{~h}$ for oestrogen and cAMP production, $72 \mathrm{~h}$ for induction of tPA enzyme activity, $24 \mathrm{~h}$ for cytochrome $\mathrm{P} 450$ aromatase $\left(\mathrm{P} 450_{\text {arom }}\right)$ and $\alpha$-inhibin mRNA production and $12 \mathrm{~h}$ for tPA mRNA expression), media were collected and either stored frozen at $-70{ }^{\circ} \mathrm{C}$ until quantitation of oestrogen and cAMP or dried by vacuum centrifugation and immediately processed for determination of tPA enzyme activity. Cells were scraped with a rubber policeman and the content of wells belonging to the same incubation group pooled and processed for total RNA isolation as described below.

\section{Radioimmunoassays}

RIA of LH and FSH Purified human FSH (human FSH-I1, National Institute of Diabetes, Digestive and Kidney Disease, National Hormone and Pituitary Program (NHPP), Torrance, CA, USA) was iodinated by the lactoperoxidase-glucose oxidase method (Bex \& Corbin 1981). After separation of the protein-bound and free iodine-125 by Sephadex G-100 (Pharmacia) column chromatography, ${ }^{125}$ I-labelled FSH was further purified by concanavalin A chromatography (Pharmacia) as described by Dufau et al. (1972). The RIA was performed using reagents provided by the NHPP. The reference preparation LER-907 (which contains almost all FSH charge isoforms detected in crude pituitary extracts (Chappel et al. 1986)) was used to construct the standard curve and anti-human FSH-6 was used at a final dilution of $1: 250000$. This antiserum exhibits less than $0 \cdot 1 \%$ crossreactivity with highly purified human $\mathrm{LH}$ and undetectable reactivity with highly purified free $\alpha$-subunit. In this RIA system, all isoforms displaced ${ }^{125}$ I-labelled FSH from the antibody in a parallel fashion when tested at seven to 10 different dilutions; in fact, simultaneous curve fitting of the dose-response curves revealed no significant differences among the slopes generated by FSH present in the LER907 standard and the several isoform pools fractionated by chromatofocusing (Zambrano et al. 1996). FSH concentrations were expressed in terms of the FSH-I1 standard unless indicated otherwise. The LH RIA was performed using ${ }^{125}$ I-labelled LH (LH-I1) as the tracer, anti-human LH-2 as antiserum and LER-907 as the curve standard (NHPP). For both RIAs, the inter- and intra-assay coefficients of variation were $<13 \%$ and $<8 \%$ respectively.

RIA of oestradiol-17 $\beta$ The amount of oestrogens released into the medium was determined using an antiserum against oestradiol-17 $\beta$ kindly provided by the Cuba-Mexico World Health Organization RIA Reagents Program at a final dilution $1: 210000$. Cross-reactivity of this antiserum was $<0.02 \%$ with cortisol, progesterone and testosterone, $0 \cdot 8 \%$ with oestriol and $22 \%$ with oestrone. Results are expressed as total oestrogens released from granulosa cells in culture. All samples from a single 
experiment were assayed in the same RIA. The intra-assay coefficient of variation was less than $4 \%$, and the sensitivity was $6.3 \mathrm{pg} /$ tube.

RIA of cAMP The cAMP RIA was performed using 2-O-monosuccinyl cAMP tyrosylmethyl ester (Sigma) radiolabelled by the chloramine $\mathrm{T}$ method and a cAMP antiserum (anti-cAMP C-1B) prepared in one of our laboratories (P M C). This antiserum showed $<0 \cdot 1 \%$ crossreactivity with cGMP, $2^{\prime}, 3^{\prime}$-cAMP, $5^{\prime}$-cAMP, $3^{\prime}$-cAMP, ADP, GDP, ATP, CTP and MIX. After incubation at $4{ }^{\circ} \mathrm{C}$ for $24 \mathrm{~h}$, antibody-bound and free cAMP were separated by ethanolic precipitation followed by centrifugation at 3000 r.p.m. for $15 \mathrm{~min}$ at $4{ }^{\circ} \mathrm{C}$. The sensitivity of the assay was $4 \mathrm{fmol} /$ tube. All samples from a single experiment were analysed in the same assay. The intra-assay coefficient of variation was $<6 \%$.

\section{Detection of tPA enzyme activity}

Detection of tPA enzyme activity was assessed by zymography using the method of Heussen \& Dowdle (1980) optimized for samples from culture medium (Timossi et al. 1998a). Semiquantitative estimation of tPA-mediated protease activity detected in pooled vacuum-centrifugation-dried media was performed by densitometric scanning using a digital image analyser (Eagle-Eye II, Stratagene, La Jolla, CA, USA). As the urokinase-type plasminogen activator (uPA) enzyme activity was not altered by FSH treatment, relative amounts of tPA enzyme activity could be standardized with the corresponding uPA-dependent protease activity in the same gel. Results are expressed as the tPA : uPA relative $\mathrm{OD}$ ratio - the ratio of the lytic area corresponding to tPA relative to that stimulated by uPA.

\section{RNA extraction and northern blot hybridization analysis}

Total RNA from granulosa cells was isolated by the single-step acid guanidinium thiocyanate-phenolchloroform method (Chomczynski \& Sacchi 1987) using the TriZol reagent (Gibco), following the instructions supplied by the manufacturer. Approximately $20 \mu \mathrm{g}$ total RNA extracted from three individual culture wells were electrophoresed on 1\% denaturing agarose gels (Sambrook et al. 1989). Thereafter the RNA was transferred to nylon membranes (Z-probe GT, Bio-Rad), u.v. cross-linked (Stratalinker 1800 , Stratagene) and prehybridized with $25 \mathrm{mM} \mathrm{Na} \mathrm{HPO}_{4}-7 \%$ SDS-1 mM EDTA, pH 8.0 at $65{ }^{\circ} \mathrm{C}$ for $4 \mathrm{~h}$. A specific phosphorus-32- or digoxigeninlabelled cDNA probe for rat tPA (provided by Dr Tor Ny, University of Umea, Umea, Sweden), rat P450 arom (kindly provided by Dr JoAnne S Richards, Department of Cell Biology, Baylor College of Medicine, Houston, TX, USA), or human $\alpha$-inhibin (Genentech, San Francisco CA, USA; $80 \%$ homology with the rat $\alpha$-inhibin cDNA sequence (according to Genestream II Networks Servers for Biology, 1Align Online Software, Institut de Gènètique Humaine, Montpellier, France)) was added to the membrane and hybridized over 16-18 h. The filters were then washed at high stringency and autoradiographed on X-Omat AR films (Eastman Kodak de México, México DF, Mexico) or incubated with an anti-digoxigenin, alkaline phosphate-conjugated antibody and thereafter with the chemiluminiscence substrate CDP-STAR (Boehringer Mannheim Bioquímica, México DF, Mexico) and exposed for 3-10 min to X-Omat AR films. Semiquantitative analysis of each specific mRNA was performed by densitometric scanning of the films. Results are expressed as the amount of mRNA relative to that of $18 \mathrm{~S}$ rRNA, in OD units.

\section{Reverse transcription-polymerase chain reaction (RT-PCR)}

Specific mRNA production was also assessed by semiquantitative RT-PCR assay. Briefly, $2 \mu \mathrm{g}$ total RNA sample were reverse-transcribed (PCR Superscript, Gibco) in a volume of $20 \mu \mathrm{l}$ containing 200 UI reverse transcriptase $\mathrm{MuLV}$, a deoxynucleotide mixture (dNTPs) and oligo-dT as transcription primer, for $60 \mathrm{~min}$ at $42{ }^{\circ} \mathrm{C}$. The cDNA obtained was subjected to PCR amplification using specific oligonucleotide primers for each cDNA (Table 1). Each reaction contained 2.5 IU Taq polymerase (Perkin Elmer, Foster City, CA, USA), $2 \mathrm{mM}$ primer pairs and $1 \mathrm{mM}$ dNTPs in PCR buffer I (Perkin Elmer). Paired reactions were carried out using $100 \mathrm{ng}$ RNA to detect amplification from contaminating genomic DNA and one additional tube per asssay containing no cDNA to detect contamination. Tubes were incubated in a thermal cycler (Thermal Cycler 9600, Perkin Elmer) for 30 cycles as follows: $15 \mathrm{~s}$ at $94{ }^{\circ} \mathrm{C}, 30 \mathrm{~s}$ at $50{ }^{\circ} \mathrm{C}$ and $45 \mathrm{~s}$ at $72{ }^{\circ} \mathrm{C}$ for P450 arom mRNA; $15 \mathrm{~s}$ at $94{ }^{\circ} \mathrm{C}, 30 \mathrm{~s}$ at $54{ }^{\circ} \mathrm{C}$ and $45 \mathrm{~s}$ at $72{ }^{\circ} \mathrm{C}$ for tPA mRNA and glyceraldehyde-3-phosphate dehydrogenase (G3PD). For $\alpha$-inhibin mRNA, incubations were performed for 15 cycles, $15 \mathrm{~s}$ at $94{ }^{\circ} \mathrm{C}, 30 \mathrm{~s}$ at $54{ }^{\circ} \mathrm{C}$, and $75 \mathrm{~s}$ at $72{ }^{\circ} \mathrm{C}$. Extension time for all last cycles was $7 \mathrm{~min}$. The PCR products so obtained were then electrophoresed in a $1 \%$ agarose gel for $30 \mathrm{~min}$ at $50 \mathrm{~V}$ and the gels dyed with ethidium bromide and digitalized in an image analyser (Eagle-Eye II, Stratagene). Individual PCR reactions were standardized to that of G3PD and are expressed as relative OD ratios.

\section{Statistical analysis}

One-way analysis of variance (ANOVA) was used to determine between-group differences in biological to immunological (B/I) FSH activity ratios and cAMP production responses. When differences existed, Bonferroni protected $t$-tests were used to determine which means were different. Probabilities $<0.05$ were considered statistically significant. 
Table 1 Primer oligonucleotide sequences used to amplify the cDNA sequences as described in Material and Methods

\begin{tabular}{|c|c|c|c|}
\hline \multirow[b]{2}{*}{ cDNA } & \multicolumn{2}{|l|}{ Sequence } & \multirow[t]{2}{*}{ Reference } \\
\hline & & & \\
\hline \multirow[t]{2}{*}{ Aromatase } & Sense & CTTGTGGATGGGGATTGGAAG & Rappaport \& Smith 1996 \\
\hline & Antisense & ССАССАGАATTTCGАTСТСGTC & Rappaport \& Smith 1996 \\
\hline \multirow[t]{2}{*}{ G3PD } & Sense & GTAGCCATATTCATTGTCATA & * \\
\hline & Antisense & AATGCATCCTGCACCACCAA & * \\
\hline \multirow[t]{2}{*}{ Rat $\alpha$-inhibin } & Sense & TGTCTCCCAGGCСАTССТTTTCССА & * \\
\hline & Antisense & AAATGAAGCTGGGAGGGTGTACGATC & * \\
\hline \multirow[t]{2}{*}{$\mathrm{tPA}$} & Sense & GGCAATCGGGTGGAATACTGC & * \\
\hline & Antisense & GAATTCCATGGGATTCAGGAG & * \\
\hline
\end{tabular}

*Sequences obtained from the OLIGO 4.0 software, National Biosciences Inc., Plymouth, MN, USA

\section{Results}

Separation of anterior pituitary glycoprotein extracts through chromatofocusing columns disclosed the presence of multiple distinct peaks of FSH and LH immunoreactivity with $\mathrm{pH}$ values ranging from $>7 \cdot 1$ to $<3 \cdot 75$ (Fig. 1). Fractions comprising the various major FSH peaks (I-VII in Fig. 1) were processed as described in Materials and Methods and tested for in vitro bioactivity. All isoform concentrates displaced ${ }^{125}$ I-labelled FSH from the antibody and from cultured granulosa cells in a dosedependent manner in parallel with the results obtained with LER-907 and highly purified human FSH (not shown).

In preliminary experiments, cultured granulosa cells exposed to human recombinant FSH (rFSH; Org32489, Organon International BV, Oss, Holland) for 6, 12, 24, 48, 60 and $72 \mathrm{~h}$ produced progresssively more oestrogen, cAMP and tPA enzyme activity, with $48-72 \mathrm{~h}$ of exposure to $\mathrm{rFSH}$ being most effective for oestrogen production, $48 \mathrm{~h}$ for cAMP accumulation and $72 \mathrm{~h}$ for tPA enzyme activity (not shown). As previously reported (Timossi et al. 1998a), the capacity of isoform concentrate I to stimulate androgen aromatization and cAMP production and induce tPA enzyme activity was considerably reduced compared with that exhibited by the less acidic, mid-acidic and strongly acidic isoforms (not shown). In contrast, incubation of rat granulosa cells in culture with increasing doses $(0 \cdot 18-3 \cdot 0 \mathrm{ng})$ of FSH isoforms II-VII for $48 \mathrm{~h}$, stimulated significant dose-dependent oestrogen (Fig. 2) and cAMP production (not shown). The in vitro biological activity (expressed as the $\mathrm{B} / \mathrm{I}$ activity ratio) of isoforms II-VII, decreased as the elution $\mathrm{pH}$ value of the corresponding isoform declined (Table 2). cAMP production was also significantly $(P<0 \cdot 05)$ greater when the cells were stimulated by FSH isoforms with elution $\mathrm{pH}$ values $6 \cdot 60$ to $4.60 \quad\left(\mathrm{ED}_{50}\right.$ values: isoform $\mathrm{II}=2 \cdot 44 \pm 0 \cdot 1$; $\mathrm{III}=2 \cdot 48 \pm 0 \cdot 09 ; \quad \mathrm{IV}=2 \cdot 48 \pm 0 \cdot 09 ; \quad$ mean \pm s.D. $) \quad$ than when they were incubated with isoforms with $\mathrm{pH}$ values $4 \cdot 76$ to $<3.80 \quad\left(\mathrm{ED}_{50}\right.$ values: isoform $\mathrm{V}=2 \cdot 70 \pm 0 \cdot 15$;
$\mathrm{VI}=2 \cdot 89 \pm 0 \cdot 20 ; \mathrm{VII}=2 \cdot 78 \pm 0 \cdot 16)$. Similar effects were observed when induction of tPA enzyme activity by cultured granulosa cells exposed to $2 \cdot 8 \mathrm{ng}$ (a dose to provoke nearly maximal response to LER-907 or human recombinant FSH in terms of oestrogen production (Fig. 2) or tPA enzyme activity (Timossi et al. 1998a)) of these FSH isoforms for $72 \mathrm{~h}$ was measured as the biological end point (Fig. 3).

In granulosa cells exposed to $\mathrm{rFSH}$ for periods ranging from 6 to $72 \mathrm{~h}$, maximal $\mathrm{P} 450_{\text {arom }}$ mRNA levels were observed after $24 \mathrm{~h}$ of FSH exposure, whereas those

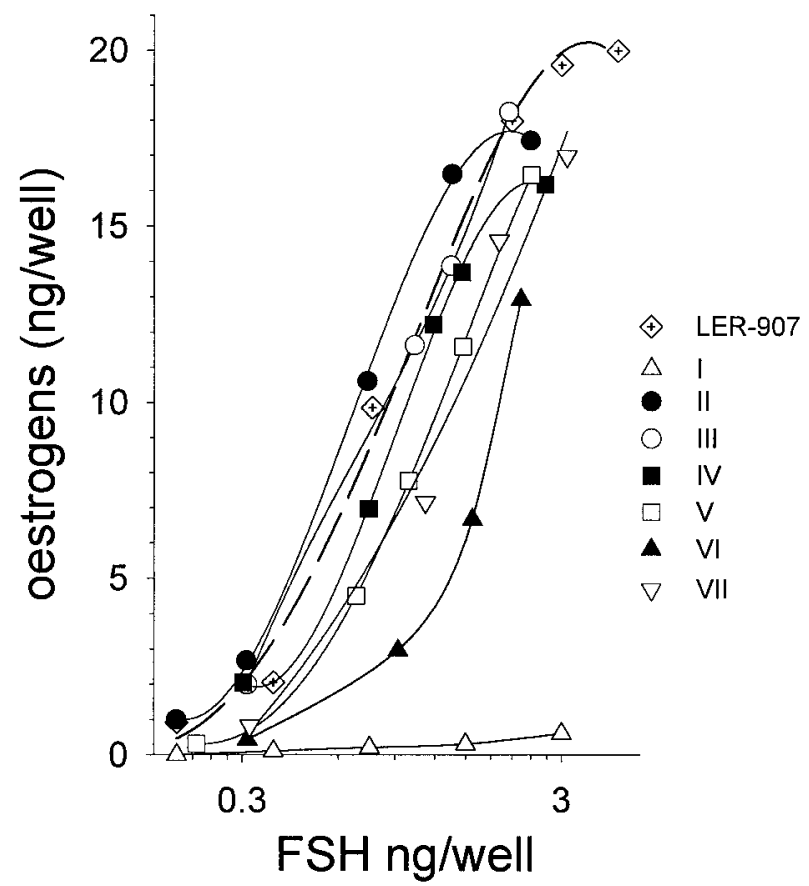

Figure 2 The ability of increasing doses of isoforms I-VII and LER-907 to stimulate oestrogen production by rat granulosa cells in culture. The dose is expressed in terms of human $\mathrm{FSH}-\mathrm{I}-3$ (NHPP) as measured by RIA, assuming that the immunological potency is equal for all preparations. 
Table 2 Biological to immunological activity ratio (B/I) of FSH isoforms recovered from different $\mathrm{pH}$ regions or boundaries after preparative chromatofocusing of pituitary extracts. Immunological and biological potencies were assessed by RIA and the in vitro aromatization assay respectively

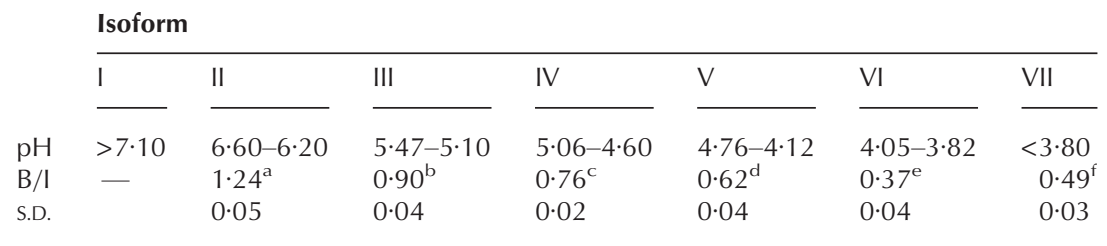

${ }^{\mathrm{a}-\mathrm{f}}$ Significant differences $(P<0 \cdot 05)$ among isoforms (one-way analysis of variance and Bonferroni protected $t$ tests).

corresponding to tPA mRNA showed two peaks of maximal production, the first occurring $12 \mathrm{~h}$ and the second $60 \mathrm{~h}$ after exposure to $\mathrm{rFSH}$ (not shown). The effect of the isoforms on $\mathrm{P} 450_{\text {arom }}$ and tPA mRNA levels is shown in Figs 4-6. Incubation of cultured granulosa cells in the presence of $2.8 \mathrm{ng} /$ well isoforms II-VII or the LER-907 standard for $48 \mathrm{~h}$ resulted in the induction of the
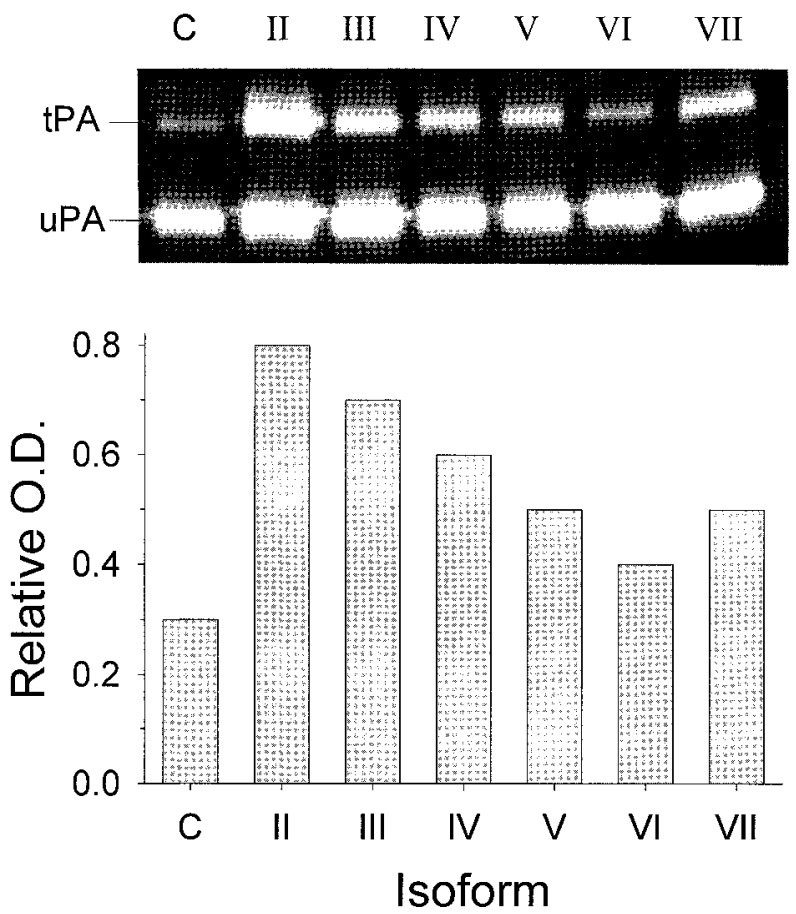

Figure 3 Upper panel: Detection of tPA enzyme activity in conditioned media from granulosa cells exposed to $\mathrm{FSH}$ isoforms. The location of tPA $\left(M_{\mathrm{r}} \sim 70000\right)$ and high molecular weight $\left(M_{\mathrm{r}}\right.$ $\sim 50$ 000) urokinase-type plasminogen activator (uPA) activities are noted. No proteolytic activity with $M_{r} \sim 70000$ or $M_{r}$ $\sim 50000$ was detected when plasminogen was omitted from the polyacrylamide gels (not shown). Lower panel: Relative OD (tPA/UPA OD ratio) of the lytic areas from the zymograph shown above. The results are representative of three independent experiments. $\mathrm{C}$, control incubation in the absence of $\mathrm{FSH}$. previously reported (Hickey et al. 1990) three $\mathrm{P} 450_{\text {arom }}$ mRNA transcripts $(3 \cdot 3,2.6$ and $1.9 \mathrm{~kb}$ in size) as disclosed by northern blot hybridization analysis (Fig. 4). The same mRNA transcripts were also detected in total RNA extracted from ovarian tissue of 18-day-pregnant rats used as a positive control (Richards 1994). Less acidic isoforms, specifically isoforms II, III and IV ( $\mathrm{pH} 6 \cdot 60$ to 4.60), exhibited greater capacity to induce $\mathrm{P} 450_{\text {arom }}$ mRNA than their more acidic counterparts (Fig. 4A). Comparable results regarding the potency of isoforms to induce $\mathrm{P} 450_{\text {arom }}$ mRNA were found by semiquantitative RT-PCR (Fig. 4B). Granulosa cells exposed to equivalent amounts of isoforms II-VII during a 12-h period produced tPA mRNA in a fashion similar to that observed for P450 arom mRNA, as disclosed by both northern blot hybridization and RT-PCR analysis (Fig. 5).

In a recent study (Timossi et al. 1998a), we showed that FSH isoform I, which binds to the FSH receptor and presumably possesses a low sialic acid content, behaved as an antagonist of FSH action. In the present study, we extended these observations by analysing the effects of isoform I on the FSH-induced expression of both $\mathrm{P} 450$ arom and tPA mRNA. As shown in Fig. 6, in the presence of the $\mathrm{ED}_{50}$ of $\mathrm{rFSH}$ for maximal androgen aromatization and tPA enzyme activity $(2.8 \mathrm{ng} /$ culture well $)$, isoform I antagonized the $\mathrm{rFSH}$-induced expression of $\mathrm{P} 450_{\text {arom }}$ and tPA mRNAs without blocking the production of G3PD mRNA, which is constitutively expressed by the granulosa cells.

The last end point measured in this study was induction of $\alpha$-inhibin mRNA by the pituitary FSH isoforms II-VII (the amount of isoform I available for this particular analysis was insufficient). As shown in Fig. 7A, incubation of granulosa cells for $24 \mathrm{~h}$ (time of maximum production of FSH-induced $\alpha$-inhibin mRNA) in the presence of equivalent amounts of each isoform resulted in the expression of $\alpha$-inhibin mRNA in a fashion opposite to that observed for P450 mRNA production; $\alpha$-inhibin mRNA induction was greater in incubations including the more acidic/sialylated isoforms (particularly isoform VII) than in those in which the less acidic counterparts were 
A $\quad$ B
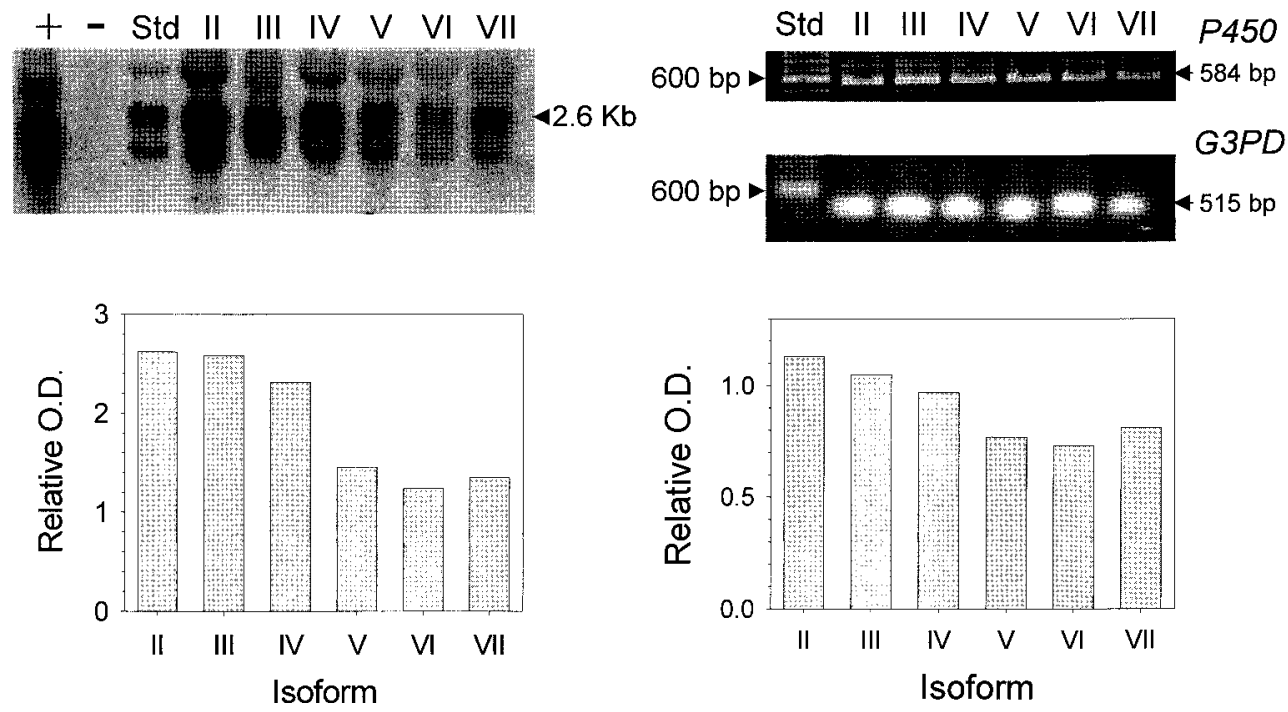

Figure 4 Cytochrome P450 arom mRNA expression in cells exposed to FSH isoforms II-VII (2.8 ng/culture well) for $48 \mathrm{~h}$. (A) Upper panel: Representative northern blot hybridization analysis of P450 arom mRNA production in response to FSH exposure. +, Positive control (ovarian tissue from 18-day-pregnant rats); - , negative control (granulosa cells cultured in the absence of FSH); Std, granulosa cells exposed to LER-907. Lower panel: Relative OD (2.6 kb P450 arom mRNA/18S rRNA OD ratio) of the autoradiograph shown above. (B) Upper and middle panels: Representative RT-PCR assay of expression of P450 arom and G3PD mRNAs in cells exposed to isoforms II-VII. Std, Molecular mass standards. Lower panel: Relative OD (584 bp reversed-transcribed $\mathrm{P} 450_{\text {arom }}$ CDNA/515 bp reverse-transcribed G3PD cDNA OD ratio) of the P450 arom and G3PD bands shown above. The results are representative of three independent experiments.

added (Fig. 7A). On the basis of previous studies indicating that oestrogens may inhibit $\alpha$-inhibin gene expression (Tate et al. 1996, Tekmal et al. 1996), we examined whether the relatively decreased production of $\alpha$-inhibin mRNA exhibited by the less acidic isoforms may be due to their enhanced ability to stimulate androgen aromatization and oestrogen production. As shown in Fig. 7B, addition of the potent oestradiol receptor antagonist ICI 182,780 or omission of androstenedione (the aromatization substrate) in incubations of cells exposed to FSH isoforms II or VII did not significantly modify the isoform-induced $\alpha$-inhibin mRNA production by cultured granulosa cells.

Finally, to rule out the possibility that the differential effect of the FSH isoforms on $\alpha$-inhibin mRNA production were actually produced by non-FSH factors that may potentially inhibit or stimulate unspecifically the production of $\alpha$-inhibin mRNA, cultured granulosa cells were incubated with isoform II or VII in the presence or absence of either rFSH or anti-human FSH-6 (at a titre sufficient to decrease significantly the androgen aromatization provoked by $\mathrm{rFSH}$, without interfering with the incubation conditions (Timossi et al. 1998a)), respectively. As shown in Fig. 8, addition of $\mathrm{rFSH}$ to wells containing isoform II increased $\alpha$-inhibin mRNA production, whereas co-incubation of isoform VII with anti-FSH decreased $\alpha$-inhibin mRNA to levels slightly greater than those detected in control and isoform II incubations (lanes 1 and 3 in Fig. 8).

\section{Discussion}

It is well known that the oligosaccharide residues of glycoprotein hormones determine several of the biological features of the hormone at the target cell level (UlloaAguirre et al. 1995). The main difference among the various isoforms is caused by charge, which in FSH is mainly determined by its content in terminal sialic acid residues (Chappel et al. 1983, Baenzinger \& Green 1988, Ulloa-Aguirre et al. 1995), although differences in nonterminal carbohydrates also play an important role in determining the heterogenous nature of the several members of the glycoprotein hormone family (Ulloa-Aguirre et al. 1988b, Papandreou et al. 1993, Creus et al. 1996). We and others have found that the receptor binding activity of the intrapituitary FSH isoforms varies depending on the charge of the isoform (Stanton et al. 1992, Ulloa-Aguirre et al. 1992, Yding Andersen et al. 1999). Less acidic/ sialylated FSH isoforms exhibit lower dissociation constants than the more sialylated counterparts when assessed by 


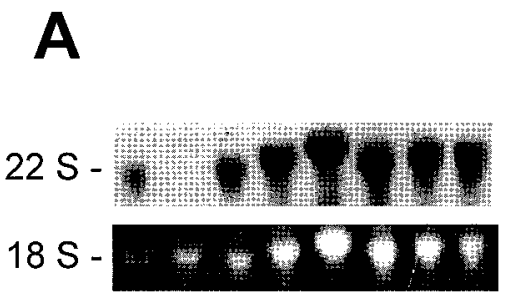

\section{B}
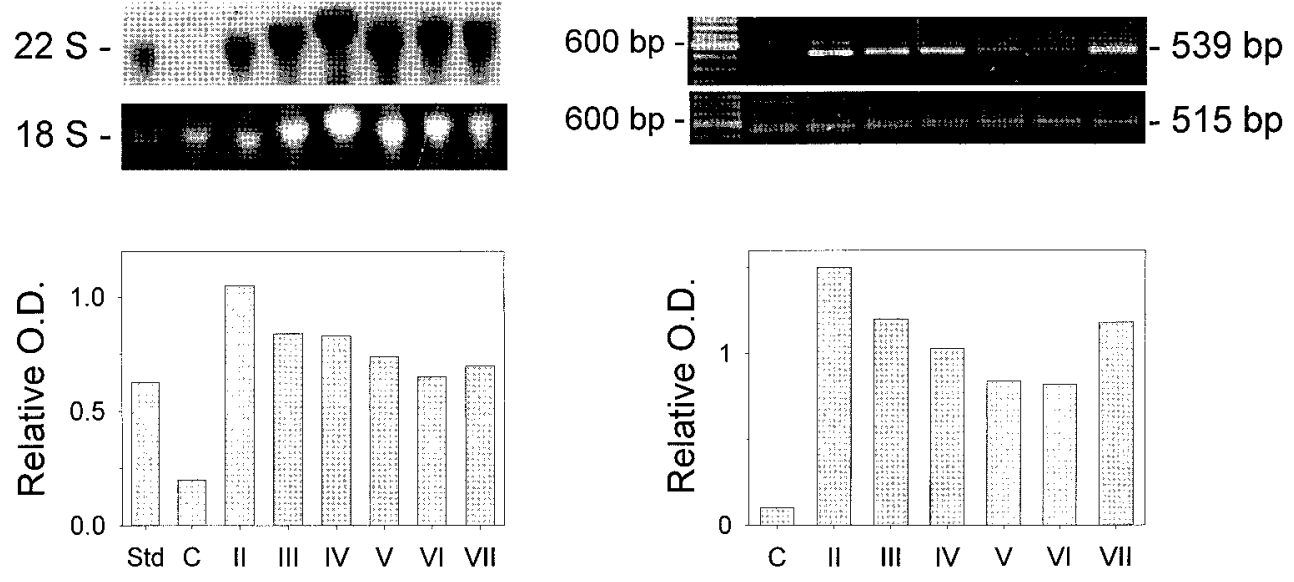

\section{Isoform}

Figure 5 Tissue-type plasminogen activator mRNA expression in cells exposed to $2 \cdot 8 \mathrm{ng} /$ culture well FSH isoforms II-VII for $12 \mathrm{~h}$. (A) Upper panel: Representative northern blot hybridization analysis of tPA mRNA expressed by FSH exposure. Middle panel: The corresponding 18S rRNA. Lower panel: Relative OD (tPA mRNA/18S rRNA OD ratio) of the tPA mRNA and 18S rRNA bands shown above. (B) Upper and middle panels: Representative RT-PCR assay of expression of tPA (539 bp) and G3PD (525 bp) mRNAs in cells exposed to isoforms II-VII. The first lane in each gel shows the migration of the molecular mass standards. Lower panel: Relative OD (reverse-transcribed tPA CDNA/reverse-transcribed G3PD cDNA OD ratio) of the tPA and G3PD cDNA bands shown above. Similar results were found in two additional experiments.

Std, Human recombinant FSH (2.8 ng/well); C, cells cultured in the absence of FSH.

heterologous receptor assay systems, which may explain the greater capacity of the former variants to stimulate oestrogen production by cultured granulosa cells (UlloaAguirre et al. 1992, Zambrano et al. 1999, present study). However, the potential exists that, depending upon the particular oligosaccharide structure of the ligand, the same

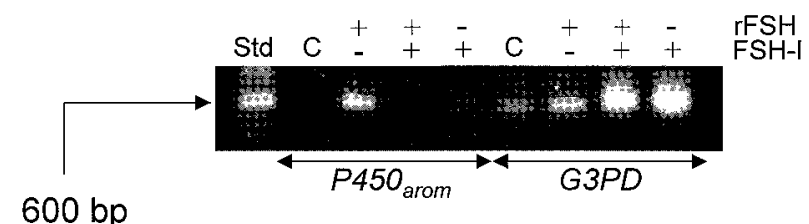

$600 \mathrm{bp}$

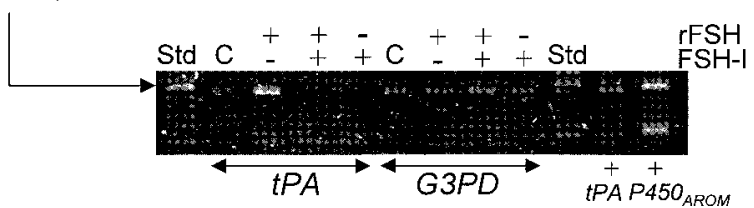

Figure 6 RT-PCR assay of expression of P450 arom (upper panel) and tPA (lower panel) mRNAs in cells exposed to $2 \cdot 8 \mathrm{ng} /$ culture well $\mathrm{rFSH}$, FSH isoform I (FSH-I) or rFSH plus FSH-I. Std, Molecular mass standards; $\mathrm{C}$, control incubations in the absence of $\mathrm{FSH}$; + tPA and + P450 $0_{\text {arom }}$ positive controls (reversed-transcribed cDNA from total RNA samples previously extracted from cells exposed to $\mathrm{rFSH}$ in which the tPA and $\mathrm{P} 450_{\text {arom }}$ mRNAs were identified by northern blot hybridization analysis). receptor or its membrane-expressed variants may produce a spectrum of cellular responses that are reflected in activation/inhibition of various intracellular signalling pathways located downstream of the receptor, thus raising the interesting possibility for isoform-specific stimulation of different functions (Arey et al. 1997). Although recent studies using glycoforms of recombinant human TSH have shown that some of the isoforms of this glycoprotein hormone may exert differential effects (Schaaf et al. 1997), data for the naturally occurring FSH variants are scarce.

The findings of the present study support the hypothesis that the glycosylation variants of FSH may evoke several cellular functions with distinct potencies. Less acidic isoforms, which presumably possess relatively low amounts of sialic acid residues and greater amounts of high mannose- and hybrid-type oligosaccharides (Creus et al. 1996), exhibited a greater capability to induce expression of cytochrome P450 arom mRNA and tPA mRNA and protein than the variants bearing more complex, highly sialylated oligosaccharides. The mechanism(s) subserving these differences in potency among the isoforms is uncertain. Using heterologous assay systems, we have found that the affinity of the less acidic human FSH isoforms for its cognate receptor is greater than that showed by the more acidic analogues, which suggests that differences in receptor affinity may account for the observed variations 


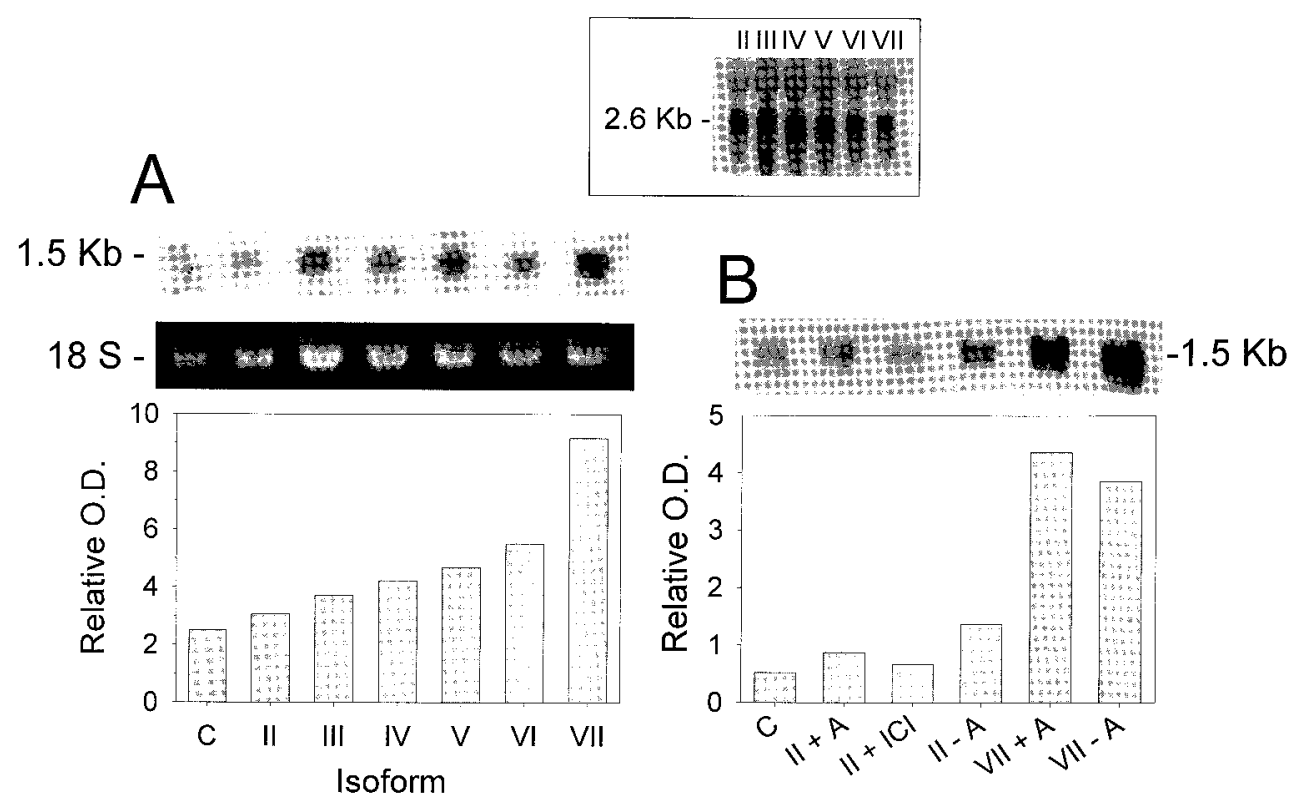

Figure $7 \alpha$-Inhibin subunit mRNA expression in granulosa cells exposed to $\mathrm{FSH}$ isoforms $(2 \cdot 8 \mathrm{ng} / \mathrm{culture}$ well) for $24 \mathrm{~h}$. (A) Upper panel: Representative northern blot hybridization analysis of $\alpha$-inhibin mRNA production induced by exposure of cells to FSH isoforms II-VII. Middle panel: The corresponding 18S rRNA bands. Lower panel: Relative OD ( $\alpha$-inhibin mRNA/18S rRNA OD ratio) of the mRNA and $18 \mathrm{~S}$ rRNA bands shown above. Similar results were found by semiquantitative RT-PCR (not shown). Inset: P450 arom mRNA expression in cells exposed to the same isoforms in a parallel experiment. (B) Upper panel: $\alpha$-Inhibin mRNA expression in cells exposed for $24 \mathrm{~h}$ to isoforms II and VII in the presence or absence of androstenedione (A) or the oestrogen receptor antagonist ICI 182,780 (ICl). Lower panel: Relative OD ( $\alpha$-inhibin mRNA/18S rRNA OD ratio) of the mRNA bands shown above. Results are representative of three independent experiments. C, Incubations in the absence of FSH.

in in vitro biopotency between the various isoforms (Zambrano et al. 1999). This possibility is supported by evidence from structural studies on human FSH, which demonstrated high correlation of binding and signal transduction (for reviews see Dias et al. 1998, Ulloa-Aguirre \& Timossi 1998). However, using a homologous assay system that presumably expresses a unique human FSH receptor population we recently found that, despite the absence of differences in receptor affinity, less acidic isoforms were more potent activators of the receptor and more effective triggers of $\mathrm{G}_{\mathrm{s}}$-mediated intracellular signal transduction than their more acidic counterparts (Zambrano et al. 1999). Taken together, these data suggest that, in addition to differences in binding, particular effects of the isoforms on signal transduction and gene expression may be also related to the diverse glycosylation-dependent abilities of the variants to induce and/or stabilize distinct receptor conformations that may permit preferential or different degrees of activation/inhibition of one or more signal transduction pathways $\left(\mathrm{G}_{\mathrm{s}}-\right.$ and/or $\mathrm{G}_{\mathrm{i}}$-mediated $)-\mathrm{a}$ mechanism also suggested for some of the differential effects exhibited by the glycoforms of TSH (Schaff et al. 1997). Finally, it has been proposed that expression of truncated or altered FSH receptor isoforms, some of which may exhibit dominant negative properties via preferential coupling to the $\mathrm{G}_{\mathrm{i}}$-mediated transducing machinery, may account for some of the pleiotropic actions of FSH (Sairam et al. 1996). Although expression of these or other receptor variants in naturally occurring cell systems (Simoni et al. 1999) may potentially contribute to the differences in in vivo bioactivity of the FSH isoforms, more studies are required before a functional role can be assigned to such receptor diversity.

In contrast to the observed effects on $\mathrm{P} 450_{\text {arom }}$ and tPA mRNA expression, the less acidic/sialylated FSH isoform mixes were less potent than the more acidic analogues as stimulators of $\alpha$-inhibin mRNA production. This divergent effect was in fact surprising, particularly considering that all biological end points measured $(\alpha$-inhibin mRNA, tPA enzyme activity and androgen aromatization) are FSH-inducible effects believed to be triggered solely by activation of the same $\mathrm{G}_{\mathrm{s}}-\mathrm{cAMP}$-dependent signalling pathway (Reichert \& Dattatreyamurty 1989, Pei et al. 1991, Fitzpatrick \& Richards 1994, Holmberg et al. 1995). Although the effect is difficult to explain on the basis of distinct ligand-receptor interactions, it is not possible to rule out the possibility of cross-talk between the FSH receptor and the insulin-like growth factor-I receptor 


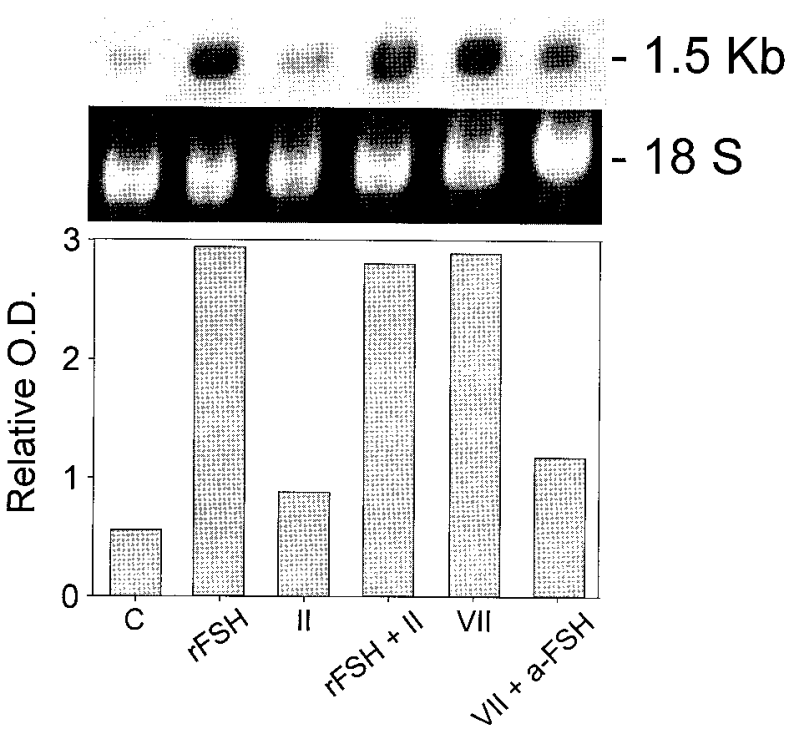

Figure $8 \alpha$-Inhibin subunit mRNA expression in granulosa cells exposed to $\mathrm{rFSH}$ or $\mathrm{FSH}$ isoforms II and VII $(2.8 \mathrm{ng} /$ culture well) in the presence or absence of either $\mathrm{rFSH}$ or human $\mathrm{FSH}$ antiserum (a-FSH; $1: 10000$ dilution) during 24 h. (A) Upper panel: Representative northern blot hybridization analysis of $\alpha$-inhibin mRNA production induced by exposure of cells to $\mathrm{rSSH}$ or $\mathrm{FSH}$ isoforms II and VII. Middle panel: The corresponding 18S rRNA bands. Lower panel: Relative OD ( $\alpha$-inhibin mRNA/18S rRNA OD ratio) of the mRNA and $18 \mathrm{~S}$ rRNA bands shown above. Similar results were found in a duplicate experiment. $\mathrm{C}$, Incubations in the absence of $\mathrm{FSH}$.

(which is involved in FSH-stimulated $\alpha$-inhibin expression (Danmei et al. 1998)) systems provoked by glycosylation-dependent diverse FSH signals that may induce and/or stabilize distinct receptor conformations, allowing for preferential or different degrees of activation/ inhibition of alternative signals. It is possible also that these divergent responses may be subserved by autocrine mechanisms triggered by the increased concentrations of oestrogen produced in response to the less acidic FSH isoforms, which in turn may amplify some specific responses $\left(\mathrm{P}^{4} 50_{\text {arom }}\right.$ and also, potentially, tPA mRNA expression; Hickey et al. 1988, Fitzpatrick \& Richards 1991, 1994) without interfering with the expression of the $\alpha$-inhibin mRNA, as disclosed by the lack of effects of androgen deprivation and oestrogen receptor blockade on inhibin $\alpha$-subunit mRNA levels. Alternatively, the attenuated $\alpha$-inhibin mRNA response to the less acidic FSH isoforms may be mediated by cAMP-dependent autoregulatory mechanisms, such as isoforms of the cAMPresponse element modulatory protein, which may act as specific early transcriptional repressors of some genes expressed in granulosa cells, including the inhibin $\alpha$-subunit gene, the expression of which is regulated by the gonadotrophin-activated $\mathrm{G}_{\mathrm{s}}-\mathrm{cAMP}$ signalling pathway (Molina et al. 1993, Mukherjee et al. 1998). Whatever the mode of action through which the FSH isoforms exert this divergent or differential effect, this finding extends those of previous studies using chemically deglycosylated ovine FSH variants (Beitinz \& Padmanabhan 1991, Padmanabhan et al. 1993, Ulloa-Aguirre et al. 1995) and strongly suggests that selective changes in FSH glycosylation not only alter the net potency of the hormone but may also elicit divergent responses at the target cell level.

We recently reported that the basically charged FSH isoform (isoform I) behaves as an antagonist of FSH action and that its inhibitory effects are specific and probably exerted at steps subsequent to cAMP formation because: (a) in low doses, this particular isoform moderately increased FSH-stimulated cAMP production by cultured granulosa cells; (b) coincubation of the antagonist isoform with dibutyryl cAMP (a potent cAMP analoge) completely inhibited the effects of the analogue on oestrogen and tPA production; (c) the isoform was able to stimulate cAMP production in a human fetal cell line expressing the recombinant human FSH receptor; (d) the inhibitory effects of this isoform on dibutyryl cAMP-provoked oestrogen and tPA production were reversed by the addition of a highly specific antibody directed against human $\mathrm{FSH}$, further demonstrating that the antagonistic effects observed were due to FSH-like molecules (Timossi et al. 1998a). In the present study, we have confirmed and extended this finding by showing that isoform I completely inhibited the FSH-dependent expression of P450 arom and tPA mRNAs, without blocking the expression of other non-gonadotrophin regulated mRNAs, such as that of the enzyme G3PD. Therefore the inhibitory effects exhibited by this isoform affected specifically the expression of those genes of which the transcription is regulated by FSH.

It should be noted that, in contrast to other studies in which highly purified preparations were used to test some in vitro actions of the FSH isoforms (reviewed in Stanton et al. 1996), in the present experiments we used isoform mixes that were only partially purified (devoid of LH, growth hormone and prolactin immunoactivities), thus raising the possibility that some of the effects observed may have been provoked by non-FSH molecules. However, several lines of evidence indicate that this was not the case. The affinity of the chromatofocusing-resolved pituitary isoform mixes for the rat and human FSH receptor was similar to that exhibited by highly purified human pituitary and recombinant FSH preparations in the same receptor systems, thus ruling out the possibility of nonspecific interference with isoform binding (Zambrano et al. 1999). Highly purified isoforms of human recombinant FSH and urinary FSH also exhibit varying potencies to evoke specific responses, with the less acidic preparations being more potent or effective than the more acidic/sialylated counterparts (Cerpa-Poljak et al. 1993. Flack et al. 1994a, de Leeuw et al. 1996, Timossi et al. 1998b, Vitt et al. 1998, D'Antonio et al. 1999). Conversely, it has been shown that chemically 
deglycosylated ovine FSH variants may evoke differential or divergent effects on androgen aromatization and $\alpha$-inhibin production by mouse Sertoli cells (Beitinz \& Padmanabhan 1991, Padmanabhan et al. 1993, UlloaAguirre et al. 1995). In the present study, exposure of granulosa cells to both isoform II and rFSH resulted in an increased production of $\alpha$-inhibin mRNA, ruling out the possibility of a contaminating factor as the cause of the decreased capability of isoform II to induce expression of this mRNA. Further, the results of the immunoneutralization experiments performed in both the present and the previously reported study (Timossi et al. 1998a) strongly suggest that the inhibitory action of the basically charged isoform on some FSH-provoked effects, in addition to the potent agonistic effect of the more acidic variant on $\alpha$-inhibin mRNA expression, were in fact the result of the specific action of FSH molecules rather than of nonspecific effects of contaminants present in the preparation. Nevertheless, further studies using highly purified pituitary FSH isoforms, with preserved bioactivity, will undoubtedly strengthen the series of data pointing toward the differential and divergent effects of the FSH isoforms at the target cell level.

In summary, the anterior pituitary gland produces different glycosylated variants of FSH with agonist or antagonist properties. The potential of the isoforms to evoke a specific effect at the target cell level differs depending on the sialic acid content (and also probably on the content of other carbohydrate residues internal to this terminal sugar (Ulloa-Aguirre et al. 1988b, Papandreou et al. 1993, Creus et al. 1996)) of the isoform. Whereas less acidic FSH isoforms are more potent in stimulating oestrogen production and tPA enzyme activity, the more acidic/sialylated analogues possess a greater potency for inducing synthesis of the $\alpha$-subunit mRNA of inhibin. These divergent effects may be critical for a more precise regulation of the ovarian response to the gonadotrophic stimulus in vivo, particularly during the periovulatory period during which a significant increase in secretion of less acidic isoforms has consistently been observed (Padmanabhan et al. 1988, Wide \& Bakos 1993, Zambrano et al. 1995, Anobile et al. 1998). In contrast, the existence of isoforms with antagonistic properties may prevent overstimulation of the growing follicle and in selected abnormal conditions may counteract in excess the physiological gonadotrophic stimulus leading to a hypogonadal state (Dumestic et al. 1993). Further studies are still needed to clarify in more detail the biochemical mechanisms subserving this variety of responses to the FSH signal during the course of regulated follicular growth and maturation.

\section{Acknowledgements}

The authors are indebted to the NIDDK for the human FSH RIA reagents, the Cuba-Mexico World Health
Organization RIA Reagents Program for the antioestradiol-17 $\beta$ antibody and to Dr Victor Sales and Dr José Luis Velázquez from Zeneca Farma, Mexico, for the ICI 182,780. This work was supported by grants from the Consejo Nacional de Ciencia y Tecnología (CONACyT) (28589-N and 0004P-N9505; to A U-A), Mexico, a Fogarty International Research Collaboration Award (FIRCA)(R03 TW00979; to P M C and A U-A) from the NIH, USA and a USPHS grant (HD 23812; to V P).

\section{References}

Anobile CJ, Talbot JA, McCann SJ, Padmanabhan V \& Robertson WR 1998 Glycoform composition of serum gonadotrophins through the normal menstrual cycle and in the post-menopausal state. Molecular Human Reproduction 4 631-639.

Arey BJ, Stevis PE, Deecher DC, Shen ES, Frail DE, Negro-Vilar A \& Lopez FJ 1997 Induction of promiscuous G protein coupling of the follicle-stimulating hormone (FSH) receptor: a novel mechanism for transducing pleitropic actions of FSH isoforms. Molecular Endocrinology 11 517-526.

Baenzinger JU \& Green DE 1988 Pituitary glycoprotein hormone oligosaccharides: structure, synthesis and function of asparagine linked oligosaccharides on lutropin, follitropin and thyrotropin. Biochemica et Biophysica Acta 947 287-306.

Barrios de Tomasi J, Merchant H, Quintanar A, Avalos JM \& Ulloa-Aguirre A 1999 in vivo effects of human follicle-stimulating hormone (FSH) isoforms on follicular growth. In Proceedings of the 32nd Annual Meeting of The Society for the Study of Reproduction, Pullman, Washington, USA, abstract 571. The Society for the Study of Reproduction July 31-August 31999.

Beitinz IZ \& Padmanabhan V 1991 Bioactivity of gonadotropins. In Endocrinology and Metabolism Clinics of North America, vol 20, pp 85-120. Ed D Styne. Philadelphia: WB Saunders.

Bex FJ \& Corbin A 1981 Luteinizing hormone-releasing hormone (LHRH) and LHRH agonist termination of pregnancy in hypophysectomized rats: extrapituitary site of action. Endocrinology 108 273-280.

Boothby M, Ruddon RW, Anderson C, McWilliams D \& Boime I 1981 A single gonadotropin alpha-subunit gene in normal tissue and tumor-derived cell lines. Journal of Biological Chemistry 256 5121-5127.

Cerpa-Poljak A, Bishop LA, Hort YJ, Chin CKH, DeKroon R, Mahler SM, Smith GM, Stuart MC \& Schofield PR 1993 Isoelectric charge of recombinant human follicle-stimulating hormone isoforms determines receptor affinity and in vitro bioactivity. Endocrinology 132 351-356.

Chappel SC, Ulloa-Aguirre A \& Coutifaris C 1983 Biosynthesis and secretion of follicle-stimulating hormone. Endocrine Reviews $\mathbf{4}$ 179-211.

Chappel SC, Bashey HM \& Snyder PJ 1986 Similar isoelectric profiles of FSH from gonadotroph cell adenomas and non-adenomatous pituitaries. Acta Endocrinologica 113 311-316.

Chomczynski P \& Sacchi N 1987 Single step method of RNA isolation by acid guanidinium thiocyanate-phenol-chloroform extraction. Analytical Biochemistry 162 156-159.

Creus S, Pellizzari E, Cigorraga SB \& Campo S 1996 FSH isoforms: bio and immuno-activities in post-menopausal and normal menstruating women. Clinical Endocrinology 44 181-189.

Danmei L, Kubo T, Kim H, Shimasaki S \& Erickson GF 1998 Endogenous insulin-like growth factor-I is obligatory for stimulation of rat inhibin $\alpha$-subunit expression by follicle-stimulating hormone. Biology of Reproduction 58 219-225. 
D'Antonio M, Borrelli F, Datola A, Bucci R, Mascia M, Polletta P, Piscitelly D \& Papoian R 1999 Biological characterization of recombinant human follicle-stimulating hormone isoforms. Human Reproduction 14 1160-1167.

Dias JA, Lindau-Shepard B, Hauer C \& Auger I 1998 Human follicle-stimulating hormone structure-activity relationships. Biology of Reproduction $\mathbf{5 8}$ 1331-1336.

Dufau ML, Tsurahara T \& Catt KJ 1972 Interaction of glycoprotein hormones with agarose Concanavalin A. Biochemica et Biophysica Acta 278 281-292.

Dumestic DA, Padmanabhan V, Beitins IZ, Sostein JS \& Shapiro SS 1993 Elevated serum levels of immunoreactive follicle-stimulating hormone (FSH) with partial bioactivity mimics hypergonadotropic hypogonadism in women with infertility. In Proceedings of the 75 th Annual Meeting of The Endocrine Society, 9-12 June 1993. Las Vegas, Nevada, USA, abstract 1064. The Endocrine Society.

Fitzpatrick SL \& Richards JS 1991 Regulation of cytochrome P450 aromatase messenger ribonucleic acid and activity by steroids and gonadotropins in rat granulosa cells. Endocrinology 129 1452-1462.

Fitzpatrick SL \& Richards JS 1994 Identification of a cyclic adenosine $3^{\prime}, 5^{\prime}$-monophosphate-response element in the rat aromatase promoter that is required for transcriptional activation in rat granulosa cells and R2C Leydig cells. Molecular Endocrinology 8 1309-1319.

Flack MR, Bennet AP, Froehlich J, Anasti JN \& Nisula B 1994a Increased biological activity due to basic isoforms in recombinant human follicle-stimulating hormone. Journal of Clinical Endocrinology and Metabolism 79 756-760.

Flack MR, Froehlich J, Bennet AP, Anasti J \& Nisula BC $1994 b$ Site-directed mutagenesis defines the individual roles of the glycosilation sites on follicle-stimulating hormone. Journal of Biological Chemistry 269 14015-14020.

Heussen C \& Dowdle EB 1980 Electrophoretic analysis of plasminogen activators in polyacrylamide gels containing sodium dodecyl-sulfate and copolymerized substrates. Analytical Biochemistry 102 196-202.

Hickey GJ, Chen S, Besman MJ, Sively JE, Hall PF, Gaddy-Kurten D \& Richards JS 1988 Hormonal regulation, tissue distribution and content of aromatase cytochrome P450 mRNA and enzyme in rat ovarian follicles and corpora lutea: relationship to estradiol biosynthesis. Endocrinology 122 1426-1436.

Hickey GJ, Krasnow JS, Beattie WG \& Richards JS 1990 Aromatase cytochrome $\mathrm{P} 450$ in rat ovarian granulosa cells before and after luteinization: adenosine $3^{\prime}, 5^{\prime}$-monophosphate-dependent and independent regulation. Cloning and sequencing of rat aromatase cDNA and 5' genomic DNA. Molecular Endocrinology 4 3-12.

Holmberg M, Leonardsson G \& Ny T 1995 The species-specific differences in the cAMP regulation of the tissue-type plasminogen activator gene between rat, mouse and human is caused by a one-nucleotide substitution in the cAMP-responsive element of the promoters. European Journal of Biochemistry 231 466-474.

Jones LR, Benker G \& Salacinski PR 1979 Large scale preparation of highly purified pyrogen free human growth hormone for clinical use. Journal of Endocrinology 82 77-83.

de Leeuw R, Mulders J, Voortman G, Rombout F, Damm J \& Kloosterboer L 1996 Structure-function relationship of recombinant follicle-stimulating hormone (Puregon). Molecular Human Reproduction 2 361-369.

Molina CA, Foulkes NS, Lalli E \& Sassone-Corsi P 1993 Inducibility and negative autorregulation of CREM: an alternative promoter directs the expression of ICER, an early response repressor. Cell $\mathbf{7 5}$ 875-886.

Morell AG, Gregoriadis G, Scheinberg IH, Hickman J \& Ashwell G 1971 The role of sialic acid in determining the survival of glycoprotein hormones in the circulation. Journal of Biological Chemistry 246 1461-1467.

Mukherjee A, Urban J, Sassone-Corsi P \& Mayo KE 1998 Gonadotropins regulate inducible cyclic adenosine $3^{\prime}, 5^{\prime}$-monophosphate early repressor in the rat ovary: implications for inhibin $\alpha$ subunit gene expression. Molecular Endocrinology 12 785-800.

Padmanabhan V, Lang LL, Sonstein J, Kelch RP \& Beitins IZ 1988 Modulation of serum follicle-stimulating hormone bioactivity and isoforms distribution by estrogenic steroids in normal women and in gonadal disgenesis. Journal of Clinical Endocrinology and Metabolism 67 465-473.

Padmanabhan V, Kersey KA, Sairam MR, Cole LA, Ireland JJ \& Beitins IZ 1993 A multiple end point bioassay to assess physiological relevance of FSH heterogeneity. In Proceedings of the 75 th Annual Meeting of The Endocrine Society, 9-12 June 1993. Las Vegas, Nevada, USA, abstract 182. The Endocrine Society.

Papandreou M-J, Asteria C, Petterson K, Ronin C \& Beck-Peccoz P 1993 Concanavalin A affinity chomatography of human serum gonadotropins: evidence for changes of carbohydrate structure in different clinical conditions. Journal of Clinical Endocrinology and Metabolism 76 1008-1013.

Pei L, Dodson R, Schoderbek WE, Maurer RA \& Mayo KE 1991 Regulation of the alpha inhibin gene by cyclic adenosine $3^{\prime}, 5^{\prime}$-monophosphate after transfection into rat granulosa cells. Molecular Endocrinology 5 521-534.

Phillips DJ, Albertsson-Wikland K, Eriksson K \& Wide L 1997 Changes in the isoforms of luteinizing hormone and folliclestimulating hormone during puberty in normal children. Journal of Clinical Endocrinology and Metabolism 82 3103-3106.

Pierce JG \& Parsons TF 1981 Glycoprotein hormones: structure and function. Annual Review of Biochemistry 50 465-495.

Pierce JG, Bahl OP, Cornell JS \& Swaminathan N 1971 Biologically active hormones prepared by recombination of the alpha chain of human chorionic gonadotropin and the hormone-specific chain of bovine thyrotropin or of bovine luteinizing hormone. Journal of Biological Chemistry 246 2321-2324.

Rappaport MS \& Smith EP 1996 Insulin-like growth factor I inhibits aromatization induced by follicle-stimulating hormone in rat sertoli cell culture. Biology of Reproduction 54 446-452.

Reichert LE Jr \& Dattatreyamurty B 1989 The follicle-stimulating hormone (FSH) receptor in testis: interaction with $\mathrm{FSH}$, mechanism of signal transduction and properties of the purified receptor. Biology of Reproduction 40 13-26.

Richards JS 1994 Hormonal control of gene expression in the ovary. Endocrine Reviews 15 725-751.

Sairam MR 1989 Role of carbohydrates in glycoprotein hormone signal transduction. FASEB Journal 3 1915-1926.

Sairam MR \& Bhargavi GN 1985 A role for the glycosylation of the $\alpha$ subunit in transduction of biological signal in glycoprotein hormones. Science 229 65-67.

Sairam MR, Jiang LG, Yarney TA \& Khan H 1996 Follitropin signal transduction: alternative splicing of the FSH receptor gene produces a dominant negative form of the receptor which inhibits hormone action. Biochemical and Biophysical Research Communications 226 717-722.

Sambrook J, Fritsch EF \& Maniatis T (eds) 1989 Molecular Cloning: a Laboratory Manual, edn 2. Cold Spring Harbor: Cold Spring Harbor Laboratory Press.

Schaaf L, Leiprecht A, Saji M, Hübner U, Usadel KH \& Kohn LD 1997 Glycosylation variants of human TSH selectively activate signal transduction pathways. Molecular and Cellular Endocrinology 132 185-194.

Simoni M, Gromoll J, Höppner W, Kamischke A, Krafft T, Stähle D \& Nieschlag E 1999 Mutational analysis of the follicle-stimulating hormone (FSH) receptor in normal and infertile men: identification and characterization of two discrete FSH receptor isoforms. Journal of Clinical Endocrinology and Metabolism 84 751-755.

Stanton PG, Robertson DM, Burgon PG, Schmauk-White B \& Hearn MTW 1992 Isolation and physicochemical characterization of human follicle-stimulating hormone isoforms. Endocrinology $\mathbf{1 3 0}$ 2820-2832. 
Stanton PG, Burgon PG, Hearn MTW \& Robertson DM 1996 Structural and functional characterisation of hFSH and hLH isoforms. Molecular and Cellular Endocrinology 125 133-141.

Tate S, Suganuma N, Furuhashi M, Ando T, Asada Y, Kondo I, Kikkawa F \& Tomoda Y 1996 Direct effects of estradiol and tamoxifen on gene expressions of inhibin alpha- and beta A-subunits in rat granulosa cells in vitro. Endocrine Journal 43 621-628.

Tekmal RR, Burns WN, Rao DV, Montoya IA, Chang PL, Stoica G \& Schenken RS 1996 Regulation of rat granulosa cell $\alpha$-inhibin expression by luteinizing hormone, estradiol and progesterone. American Journal of Obstetric and Gynecology 2 420-426.

Timossi CM, Barrios de Tomasi J, Zambrano E, Gonzalez R \& Ulloa-Aguirre A 1998a A naturally occurring basically charged human follicle-stimulating hormone (FSH) variant inhibits FSH-induced androgen aromatization and tissue-type plasminogen activator enzyme activity in vitro. Neuroendocrinology 67 153-163.

Timossi C, Damián-Matsumura P, Dominguez-Gonzalez A \& Ulloa-Aguirre A 1998b A less acidic human follicle-stimulating hormone preparation induces tissue-type plasminogen activator enzyme activity earlier than a predominantly acidic analog in phenobarbital-blocked proestrus rats. Molecular Human Reproduction 4 1032-1038.

Ulloa-Aguirre A \& Timossi C 1998 Structure-function relationship of follicle-stimulating hormone and its receptor. Human Reproduction Update 4 260-283.

Ulloa-Aguirre A, Espinosa R, Damian-Matsumura P \& Chappel SC 1988 Immunological and biological potencies of the different molecular species of gonadotropins. Human Reproduction 4 491-501.

Ulloa-Aguirre A, Espinoza R, Damian Matsumura P, Larrea F, Flores A, Morales L \& Dominguez R 19886 Studies on the microheterogeneity of anterior pituitary follicle-stimulating hormone in the female rat. Isoelectric focusing pattern throughout the estrous cycle. Biology of Reproduction 38 70-78.

Ulloa-Aguirre A, Cravioto A, Damian-Matsumura P, Jimenez M, Zambrano E \& Diaz-Sanchez V 1992 Biological characterization of the naturally occurring analogues of intrapituitary human folliclestimulating hormone. Human Reproduction 7 23-30.

Ulloa-Aguirre A, Midgley AR, Beitins IZ \& Padmanabhan V 1995 Follicle stimulating isohormones: characterization and physiological relevance. Endocrine Reviews 16 765-787.
Valove FM, Finch C, Anasti JN, Froehlich J \& Flack MR 1994 Receptor binding and signal transduction are dissociable functions requiring different sites on follicle-stimulating hormone. Endocrinology 135 2657-2661.

Vitt UA, Kloosterboer HJ, Rose UM, Mulders JWM, Kiesel PS, Bete S \& Nayudu PL 1998 Isoforms of human recombinant folliclestimulating hormone: comparision of effects on murine follicle development in vitro. Biology of Reproduction 59854 861.

Wide L 1986 The regulation of metabolic clearance rate of human FSH in mice by variation of the molecular structure of the hormone. Acta Endocrinologica 112 336-344.

Wide L \& Bakos O 1993 More basic forms of both human folliclestimulating hormone and luteinizing hormone in serum at midcycle compared with the follicular or luteal phase. Journal of Clinical Endocrinology and Metabolism 76 885-889.

Yding Andersen C, Leonardsen L, Ulloa-Aguirre A, Barrios de Tomasi J, Moore L \& Byskov AG 1999 FSH-induced resumption of meiosis in mouse oocytes: effect of different isoforms. Molecular Human Reproduction 5 726-731.

Zambrano E, Olivares A, Mendez JP, Guerrero L, Díaz Cueto L, Veldhuis JD \& Ulloa-Aguirre A 1995 Dynamics of basal and gonadotropin-releasing hormone-releasable serum follicle-stimulating hormone charge isoform distribution throughout the human menstrual cycle. Journal of Clinical Endocrinology and Metabolism 80 1647-1656.

Zambrano E, Barrios de Tomasi J, Cardenas M \& Ulloa-Aguirre A 1996 Studies on the relative in vitro biological potency of the naturally-occurring isoforms of intrapituitary follicle-stimulating hormone. Molecular Human Reproduction 2 563-571.

Zambrano E, Zariñan T, Olivares A, Barrios de Tomasi J \& Ulloa-Aguirre A 1999 Receptor binding activity and in vitro biological activity of the human FSH charge isoforms as disclosed by heterologous and homologous assay systems. Endocrine $\mathbf{1 0}$ 113-121.

Received 1 October 1999

Accepted 11 January 2000 